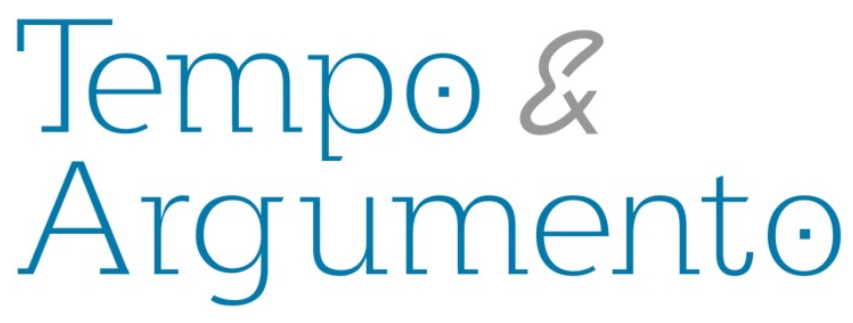

\title{
Memórias e representações dos estudantes secundaristas desaparecidos durante a última ditadura civil-militar argentina $(1976-1983)^{1}$
}

\begin{abstract}
Resumo
A proposta do presente artigo é analisar as memórias e representações produzidas acerca dos desaparecidos na Argentina pós-ditatorial. Para tanto, analisaremos um perfil específico de vítimas da repressão: estudantes secundaristas desaparecidos. Demonstraremos que este perfil foi utilizado para denunciar as violações sistemáticas aos direitos humanos cometidos ao longo dos sete anos da última ditadura civil-militar (1976-1983), principalmente para contrapor os argumentos do regime para respaldar a sua guerra contra a subversão. Apontaremos assim de que maneira se construiu desde as primeiras denúncias durante a ditadura um perfil específico de vítimas que apenas compartilhavam o fato de serem adolescentes e estudantes secundaristas quando foram sequestrados e desaparecidos. Podemos perceber que há uma permanência dessa representação ao longo da democracia, sobretudo no seu uso reiterado como um dos principais veículos de denúncia das violações contra os direitos humanos cometidas na última ditadura. Apresentaremos quais os elementos que a conformaram, assim como os que são silenciados e esquecidos nas diferentes memórias produzidas sobre os estudantes desaparecidos; e quais as consequências da sua reiteração para um entendimento crítico das condições nas quais se produziram tais desaparecimentos.
\end{abstract}

Palavras-chave: Argentina; Memória; Ditadura civil-militar; Estudantes; Desaparecidos.

\section{Para citar este artigo:}

TOLENTINO, Marcos. Memórias e representações dos estudantes secundaristas desaparecidos durante a última ditadura civil-militar argentina (1976 - 1983). Revista Tempo e Argumento, Florianópolis, v. 6, n. 11, p. 386-422, jan./abr. 2014.

\section{DOI: $10.5965 / 2175180306112014386$}

http: //dx.doi.org/10.5965/2175180306112014386

\footnotetext{
${ }^{1}$ Esta pesquisa foi realizada com o financiamento da Coordenação de Aperfeiçoamento de Pessoal de Nível Superior (CAPES), sob orientação do Prof. Dr. José Alves de Freitas Neto (UNICAMP).
} 


\title{
Memories and representations of the disappeared high school students during the last Argentine civil-military dictatorship (1976 - 1983)
}

\begin{abstract}
The purpose of this paper is to analyze the memories and representations produced about the "disappeared" in post-dictatorial Argentina, focusing on a specific profile of victims: high school students who "disappeared". This profile was used to denounce the systematic human rights violations committed over the last seven years of civil-military dictatorship (1976 - 1983), mainly to challenge the arguments of the regime to support the "war against subversion". Our goal is to point out how, as of the first complaints during the dictatorship, a specific profile of victims, who only shared the fact that they were teenagers and high school students when kidnapped and disappeared was built. We observed that there is a permanence of this representation even in democratic times, particularly in its repeated use as a major vehicle of denunciation of the human rights violations during the last civil-military dictatorship. We will then present what elements conformed this profile, as well as those that are silenced and forgotten in the different memories produced about the students who "disappeared", and the consequences of their reiteration to an critical understanding of the conditions under which such disappearances occurred.
\end{abstract}

Keywords: Argentina; Civil-military dictatorship; Memory; Students; Disappeared. 
No calendário de atividades culturais e comemorações na Argentina, setembro é o mês da juventude. Esta associação remete ao início do século XX, quando o 21 de setembro passou a ser celebrado entre os estudantes universitários como o Dia do Estudante, costume que logo foi incorporado por estudantes secundaristas. A partir da segunda metade do século XX, passou-se a celebrar nessa mesma data o Dia da primavera, quando as aulas nos estabelecimentos educativos de todos os níveis são suspensas nas principais cidades, dando aos festejos um forte caráter juvenil. Terminada a mais recente ditadura civil-militar (1976-1983) no país, ${ }^{2}$ desde os primeiros anos da democracia que a seguiu, a associação do mês de setembro como o mês da juventude reafirmou-se quando este se tornou o momento privilegiado de práticas de rememoração de um perfil específico de vítimas da repressão ditatorial: adolescentes, estudantes secundaristas.

À primeira vista, parecem claros os motivos dos estudantes argentinos escolherem o seu mês para homenagear os seus pares desaparecidos na última ditadura. Em nossa investigação, constatamos que esta escolha relacionou-se ainda com o fato de no mês de setembro ter ocorrido um dos operativos repressivos ao movimento estudantil secundarista mais notórios do período ditatorial - o episódio conhecido como La noche de los lápices. A sua forte presença nas escolas se deu com a repercussão pública que ele adquiriu ao ser citado nas páginas do Nunca Más; ao ser selecionado no Juicio a las Juntas como um dos casos paradigmáticos nos quais se basearam a ação judicial contra os

\footnotetext{
${ }^{2}$ As relações entre as sociedades dos países do Cone Sul latino-americano e as respectivas ditaduras têm sido problematizadas por pesquisadores que buscam desconstruir uma memória recorrente nas democracias que as sucederam segundo a qual o autoritarismo só teria sido possível em função de instituições e práticas coercitivas e manipulatórias. Buscam assim compreender as ditaduras como produtos sociais, e não como fruto da vontade de poucos, geralmente tidos como algozes frente a sociedades vitimizadas, analisando os correlatos a nível social de algumas das estratégias utilizadas pelas ditaduras, em uma dupla dimensão que abarca as ações e convocatórias dirigidas à sociedade, e os comportamentos exibidos por elas durante esses anos (QUADRAT; ROLLEMBERG, 2010). No caso argentino, produziu-se uma memória na qual as práticas efetivas do terror sobre os indivíduos parecem ter ocorrido distante deles. A ação da ditadura, sobretudo das Forças Armadas, aparece como a de um exército de ocupação, gerando um esquecimento do fato de que o seu programa de intervenção sobre o Estado e sobre amplos setores sociais não era alheio a tradições, ações e representações políticas compartilhadas, o que gerou expressões diversas de apoio civil (VEZZETTI, 2002, p. 39; 2011, p. 53). Logo, optaremos por utilizar a denominação ditadura civil-militar para nos referirmos a tal experiência, apesar da produção acadêmica no país ainda não adotar o termo civil, mesmo que algumas investigações já tenham demonstrado o consentimento golpista de setores da sociedade nos meses prévios ao golpe e a sua adesão à luta anti-subversiva durante a ditadura (FRANCO, 2012, p. 25-26).
} 
comandantes das Juntas Militares que governaram a Argentina durante a ditadura; e ao ter a sua história contada em um filme e um livro homônimos, ambos lançados em 1986 (LORENZ, 2007 e RAGGIO, 2009, 2010).

La noche de los lápices é o nome pelo qual se tornaram célebres os procedimentos repressivos ocorridos durante o mês de setembro de 1976, quando foi sequestrado na cidade de La Plata um grupo de estudantes secundaristas como parte da repressão ao movimento estudantil, dentre os quais estavam: Francisco López Muntaner, María Claudia Falcone, Claudio de Acha, Horacio Ángel Ungaro, Daniel Alberto Racero, María Clara Ciocchini, Pablo Díaz, Patrícia Miranda, Gustavo Calloti e Emilce Moler. A maioria deles era de militantes da Unión de Estudiantes Secundarios (UES), uma das frentes de massa dos Montoneros, com exceção de Pablo Díaz, integrante da Juventud Guevarista (JG) ligada ao Ejército Revolucionario del Pueblo (ERP), grupo que fazia parte da estrutura militar do Partido Revolucionario de los Trabajadores (PRT); e Patricia Miranda, sobre a qual não temos informações sobre sua vinculação com qualquer organização política. Desse grupo, somente os quatro últimos sobreviveram.

É importante observamos que, apesar dos jovens platenses terem sido sequestrados em diferentes datas, entre os dias 13 e 21 de setembro de 1976, o 16 de setembro tornou-se a data à qual o caso se associou. Consequentemente, de todas as noites atravessadas pelos estudantes secundaristas na última ditadura civil-militar, converteu-se na que sintetizaria as diversas experiências e trajetórias. ${ }^{3}$ Dessa forma, principalmente a partir de meados da década de 1990, tornou-se recorrente fazer da comemoração ao aniversário de La noche de los lápices um mote para homenagear outros estudantes secundaristas desaparecidos, que não possuíam qualquer vínculo com o episódio em questão além do fato de se encaixar no mesmo perfil etário e ocupacional que as suas vítimas.

\footnotetext{
${ }^{3}$ De acordo com Sandra Raggio, nomear sucessos trágicos como noites trágicas tornou-se uma estratégia recorrente para denunciar ações repressivas da mais recente ditadura civil-militar argentina. Esta metáfora possuía ainda antecedente na cultura ocidental, em outras noites utilizadas para referir-se, por exemplo, a episódios do regime nazista (RAGGIO, 2005, p. 102-103).
} 
Em setembro de 2012, com o fim de promover espaços de reflexão que ajudassem a consolidar nos estudantes da cidade de Buenos Aires os valores vinculados aos direitos humanos e à construção da memória coletiva, o Espacio para la Memoria (ex ESMA) organizou o Mês dos jovens - Participação e Direitos Humanos. A iniciativa buscava “(...) homenajear a los estudiantes secundarios secuestrados en 'La noche de los lápices', promover en los jóvenes el sentido y la valoración crítica del pasado, y estimular en ellos la participación activa en los distintos ámbitos de la sociedad.". ${ }^{4} \mathrm{~A}$ atividade que abriu a programação foi a intervenção Presentes: um projeto artístico que instalou vinte fotografias de grande formato com o rosto de estudantes secundaristas desaparecidos nas paredes dos distintos edifícios que fizeram parte da ex ESMA, todas acompanhadas de uma breve legenda nas quais se podiam ler algumas informações pessoais que convergiam para a construção de uma categoria também discriminada - estudiante secundario(a) desaparecido(a). Conformava-se assim um perfil específico de vítima da ditadura a partir de elementos comuns, apesar das diferentes trajetórias individuais: a idade no momento do desaparecimento, entre 14 e 20 anos; o fato de então frequentar algum estabelecimento educativo de nível secundário; a utilização de uma foto 3×4 que restituía a individualidade negada pela desaparição anônima e afirmava uma presença congelada em uma etapa específica da vida - a adolescência (Da Silva CATELA, 2001, p. 160).

A partir do que foi dito, o objetivo do nosso trabalho é apontar de que maneira se construiu desde as primeiras denúncias durante a ditadura um perfil específico de vítimas que apenas compartilhavam o fato de serem adolescentes e estudantes secundaristas quando sequestrados e desaparecidos. Podemos perceber que há uma permanência dessa representação ao longo da democracia, sobretudo no seu uso reiterado como um dos principais veículos de denúncia das violações contra os direitos humanos cometidas na última ditadura. Questionaremos então quais os elementos que a conformaram, assim como os que são silenciados e esquecidos nas diferentes memórias produzidas sobre os estudantes desaparecidos; e quais as consequências da sua reiteração para um entendimento crítico das condições nas quais se produziram tais desaparecimentos.

\footnotetext{
${ }^{4}$ http://sur.infonews.com/notas/septiembre-mes-de-los-jovenes-en-la-ex-esma Acesso em 19 agosto 2013.
} 
Problematizaremos principalmente a associação das jovens vítimas da ditadura ao que Marcos Novaro e Vicente Palermo denominaram como o mito das vítimas inocentes. Se a inocência dos desaparecidos deveria se basear no fato de que nenhum deles, nem mesmo os mais diretamente implicados na guerrilha e nas ações armadas, fora eximido de um tratamento criminoso, sem direito a julgamento e desaparecedor de suas identidades; esta se resumiu ao sinônimo de não subversivos, alheios à luta armada (NOVARO; PALERMO, 2007, p. 643). Segundo Hugo Vezzetti, este se tornou um dos mitos recorrentes nas narrativas produzidas sobre o passado ditatorial por se constituir “(...) como un núcleo duro y persistente sobre el que vuelve el trabajo de la memoria" (VEZZETTI, 2002, p.16-17). Nesse marco, os estudantes secundaristas eram dotados de inocência devido ao atributo natural de estarem na adolescência quando atingidos pela repressão. Consequentemente, excluíram-se do seu universo de possibilidades e escolhas as possíveis adesões a projetos políticos de cunho revolucionário, alguns que inclusive legitimavam o uso da violência.

\section{Memórias e representações dos desaparecidos na Argentina pós-ditatorial}

O desaparecimento forçado de pessoas se constituiu em uma das principais marcas da mais recente ditadura civil-militar argentina. Com o intuito de compreendermos a sua adoção como modalidade repressiva sistematicamente planejada pelas Forças Armadas, com a colaboração de forças policiais nos âmbitos federal e provincial, devemos inseri-la no histórico de práticas repressivas e de violência política que marcou a história política da Argentina da segunda metade do século XX, percebendo possíveis continuidades e rupturas. É importante termos em vista que a sua execução não teria sido possível sem a adesão e o consenso de parte da sociedade que viu no golpe de 24 de março de 1976 uma oportunidade de recuperação da ordem e da autoridade perdidas em um cenário de enfrentamento político e de crise institucional, exibindo respostas sociais à adoção de medidas definitivas na guerra contra a subversão que foram do apoio explícito à indiferença a algo que atingia ao outro, que havia se metido em algo, e que não Ihes dizia respeito. 
Segundo Marina Franco, para compreendermos a natureza da repressão durante a última ditadura devemos problematizar uma narrativa histórica que considera o 24 de março e o ano de 1976 como ícones de referência automática para uma experiência de violência radicalmente distinta e isolada historicamente dos períodos que a antecederam; um parêntesis histórico ou um pesadelo iniciado do dia para a noite. Para tanto, um dos pontos fundamentais seria considerar toda a década de 1970 como um momento de reconfiguração progressiva da violência estatal, superando a dicotomia entre ditadura e democracia, o peso dos cortes institucionais e a centralidade exclusiva do ator militar. Não se trataria, assim, de uma visão de culminação de um processo de acúmulo da violência que invariavelmente resultaria no acionar repressivo implementado a partir de 1976, pois correríamos assim o risco de realizar um exercício teleológico (FRANCO, 2011).

Pilar Calveiro aponta que, apesar da última ditadura não ter sido alheia à sociedade argentina e à sua história, ela representou uma mudança substancial ao reorganizar formas preexistentes de expressão do poder - a tortura, o sequestro, o assassinato político, o sistema carcerário - de maneira a conformar um novo poder desaparecedor em uma alusão literal: a possibilidade do Estado e da repressão política de desaparecer com o indesejado e com qualquer registro do delito cometido (CALVEIRO, 2008, p. 23-28). Poder este que, de acordo com Carlos Acuña e Catalina Smulovitz, teria sido definido antes mesmo do golpe, baseado na percepção de que os opositores políticos não deveriam apenas ser neutralizados, mas eliminados fisicamente, de maneira a garantir que não renovassem suas militâncias, como ocorrera através da Anistia de 1973 que seguiu o fim da ditadura anterior, a Revolução Argentina (ACUÑA; SMULOVITZ, 1995, p. 27-30). ${ }^{5}$ Marcos Novaro e Vicente Palermo pontuam que os militares almejavam assim dar um fim ao vírus subversivo atacando-o em todas as frentes de atuação e eliminando as suas possibilidades de perpetuação (NOVARO; PALERMO, 2007, p. 59-60). "Subversivo (...) equivalia a ser inimigo da Pátria, desta Pátria uniforme, integrada e imutável tal como a entendiam os

\footnotetext{
${ }^{5}$ Revolução Argentina foi a autodenominação das Forças Armadas para a ditadura iniciada em 28 de junho de 1966, com um golpe de Estado que depôs o então presidente Arturo Illia. Ao longo de sete anos, três militares sucederam-se no poder apoiados por organizações civis e empresariais afetadas pelas lutas sindicais do período que a precedeu. Fortemente questionada em meio a um crescente processo de mobilização popular, a ditadura terminou em 1973 com a eleição do candidato peronista Héctor J. Cámpora, encerrando assim anos de tentativa de proscrição do Peronismo.
} 
militares" (NOVARO; PALERMO, 2007, p. 116); logo, pautados na Doutrina de Segurança Nacional, entendiam-no como um ser estranho ao corpo nacional e moralmente irrecuperável, ao qual estavam excluídas as prerrogativas que o tornavam um cidadão detentor de direitos.

Devido ao alcance da violência sistematizada, que teria resultado num total de 30.000 desaparecidos segundo cifras defendidas pelo movimento argentino pelos direitos humanos (Da Silva CATELA, 2001, p. 86-88), notamos um consenso de que esta se diferenciou tanto das experiências autoritárias anteriores na Argentina, como das que vigoraram nos países vizinhos do Cone Sul latino-americano (NOVARO; PALERMO, 2007, p. 25-26, 138-39). Para Carlos Altamirano, a consequência desse reconhecimento é a persistência do passado ditatorial como um passado presente há mais de duas décadas nos debates públicos argentinos, através de uma variedade de exercícios de interpretação histórica, que nos espaços públicos se encontram com os relatos das memórias, além dos que procedem dos tribunais nos quais se julgam as causas por violações aos direitos humanos, da investigação jornalística, das produções culturais, dos pronunciamentos e iniciativas do poder político, dos discursos públicos de distintos movimentos sociais (ALTAMIRANO, 2008, p. 18-19).

Porém, não podemos compreender tal permanência como consequência apenas do alcance da violência perpetrada pelas Forças Armadas e policiais, mas também por esta violência ter se tornado objeto de conflitos de memórias, fruto da dificuldade de se gerar um consenso entre os diferentes atores sociais sobre a sua significação. Segundo Elizabeth Jelin, com o fim da ditadura, habilitou-se uma esfera pública na qual foram incorporados, além do relato político dominante produzido pelo regime, narrativas que até então se encontravam contidas na esfera privada ou censuradas, passando a enfrentar-se para afirmar como legítima e verdadeira a sua versão do passado e o acerto de contas que deveria ser feito em relação a ele. Entretanto, tais conflitos não devem se resumir a um embate entre a memória e o esquecimento e, sim, entre distintas memórias, sendo o próprio esquecimento um dos seus elementos constitutivos (JELIN, 2002, p. 3947). 
Podemos perceber, por exemplo, que atualmente na Argentina a palavra desaparecido possui um significado político e simbólico próprio; e quando utilizado logo remete a um subtexto culturalmente partilhado, a uma violência e a um tempo cronológico preciso - a desaparição forçada de pessoas durante a última ditadura (Da Silva CATELA, 2001, p. 13). Entretanto, isso não significa que o desaparecido não seja objeto de disputas, sobretudo de um conflito de identidades no qual as categorias de memória e esquecimento assumem traços paradoxais, seja nas tentativas de torná-lo uma pessoa desaparecida, com traços individuais e uma biografia prévia ao desaparecimento (KAUFMAN, 2012, p. 48), ou de se afirmar laços familiares, políticos e sociais com ele (Da Silva CATELA, 2001, p. 204).

De acordo com Ludmila da Silva Catela, o desaparecido passou a existir como uma noção de pessoa cuja identidade é formada por várias camadas e clivagens que vêm à tona a depender de quem o evoca. A explicação estaria nas consequências do desaparecimento sobre as práticas do luto, provocando a necessidade de se reinventar as formas e estratégias para lembra-lo. A ausência de um corpo e consequentemente de um túmulo fazem com que a morte não se consuma nas consciências, tornando o desaparecido o objeto de contínuos questionamentos e dúvidas. Permite ainda que cada indivíduo encontre sua forma de homenagear a sua memória, elegendo certas características, silenciando outras, expressando uma mistura de emoções e afirmações políticas próprias (Da Silva CATELA, 2001).

Segundo Emilio Crenzel, as diversas estratégias utilizadas para representar o desaparecido, dotá-lo de identidade e de uma presença pública, demonstrariam uma derrota da vontade de negação, silêncio e esquecimento da ditadura; assim como rebateriam o suposto caráter impensável, indizível e irrepresentável de experiências de violências extremas, como se afirmara no mundo ocidental a partir do genocídio nazista. Logo, a experiência argentina seria um demonstrativo da possibilidade de se superar a violência cometida e de se pensar, representar e evocar a figura dos desaparecidos mediante uma multiplicidade de aportes e veículos, como: a sua inscrição no código penal, que permitiu reestabelecer a materialidade e a veracidade do ocorrido, julgar e condenar seus responsáveis materiais e sancionar leis de reparação aos familiares; a sua 
representação em produções culturais da literatura, da música, das artes plásticas e das artes visuais; a sua evocação nos espaços urbanos através de intervenções estatais com a constituição de espaços de memória, assim como empreendimentos menores como a colocação de placas, árvores, baldosas, e a nominação de espaços públicos com nomes de desaparecidos; a sua integração ao currículo escolar, formando parte dos textos de história utilizados nas escolas médias, e possuindo datas próprias de homenagem nos calendários escolares; e a sua citação recorrente nos meios de comunicação de massa (CRENZEL, 2010, p. 13-15).

Porém, não se trata de um processo livre de conflitos: por ter sido um exercício de violência clandestino e anônimo, diferentemente da forma fixa que acompanha a imagem do indivíduo após a sua morte, o desaparecido estaria preso a incertezas e a possíveis atualizações com o passar do tempo (CRENZEL, 2008, p. 34-35), o que explicaria o caráter mutável e conflituoso que a sua representação teve na Argentina nos últimos trinta anos:

\begin{abstract}
Estas diversas representaciones han sido fruto de procesos de elaboración de la memoria social y de la intervención de diferentes actores y grupos que luchan por interpretar y dotar de sentido este pasado en la escena pública. La respuesta a la pregunta sobre quiénes han sido los desaparecidos, entonces, se ha ido modificando a través del tiempo como resultado de las diversas intervenciones narrativas $y$ simbólicas que involucraron su representación y evocación y, lejos de condensar un sentido unívoco, es aún objeto de confrontaciones (CRENZEL, 2010, p. 21).
\end{abstract}

Por outro lado, essas mesmas razões tornam-no um objeto privilegiado para investigações históricas que se dedicam ao estudo das memórias da última ditadura civilmilitar argentina. No caso específico argentino, a reivindicação da memória ou do esquecimento como consignas políticas ou como catalisadoras de políticas oficiais nem sempre incorporou uma reflexão sobre os mecanismos, as armadilhas e os paradoxos da memória. Consequentemente, a memória coletiva parecia condenada a nutrir-se exclusivamente da recordação pessoal, do testemunho judicial ou dos marcos gerais de sentido que pautavam os discursos fundantes da democracia (RABOTNIKOF, 2008: 262), já que durante anos, em um processo de profissionalização e institucionalização da história como disciplina, e de cisão entre história e política, houve censuras aos historiadores para produzir a partir de ferramentas próprias narrativas que os incluíssem 
no processo de significação do passado ditatorial (FRANCO; LEVIN, 2007, p. 56 e PITTALUGA, 2010, p. 128-129). Contudo, nos últimos anos notamos avanços em uma leitura crítica proveniente de trabalhos acadêmicos que incluíram o tema da última ditadura civil-militar em sua agenda de investigações. Em diálogo com as problemáticas da História do Tempo Presente, principalmente o pressuposto de que as representações do passado têm uma história e uma lógica temporais próprias que precisam ser compreendidas (ROUSSO, 2006, p. 95-96), partem da ideia de que as memórias passam por mudanças de sentido e conteúdo, em uma dinâmica histórica que requer ser analisada e problematizada.

De acordo com Elizabeth Jelin, tais mudanças não seriam fruto apenas de exercícios negacionistas, apesar de estes também existirem, mas de uma mudança na ênfase sobre o quê recordar e o quê preservar do passado, privilegiando e resgatando elementos que até então poderiam estar silenciados ou esquecidos. Logo, as mudanças nos cenários políticos, a entrada de novos atores sociais e as transformações nas sensibilidades poderiam implicar em transformações das significações do passado (JELIN, 2002, p. 70). Portanto, tais trabalhos geralmente abordam desde a própria ditadura, tanto por ser o período ao qual se refeririam as memórias produzidas posteriormente, quanto pelo fato de que alguns dos discursos então formulados pelo Estado, pela sociedade e pelos organismos de direitos humanos se constituiriam nas representações que alimentam os conflitos pela memória; à democracia reiniciada em 1983 e os modos como tais discursos foram se transformando (BISQUERT; LVOVICH, 2008).

Além disso, questionam quais elementos persistiram nas estratégias de representação do passado. Em relação aos desaparecidos, Gustavo Buzzone e Ana Longoni apontam que estas geralmente se formam a partir de uma série de oposições não excludentes - o massivo/o particular, o anônimo/ o nome próprio, o reclame por justiça/ a recordação íntima, o momento do desaparecimento/ a biografia prévia -, cujos contrastes e afirmações de um em detrimento do outro nos ajudam a pensar nos distintos momentos de elaboração coletiva e pessoal (BUZZONE \& LONGONI, 2008, p. 57). Esses elementos reforçam também alguns limites que ainda se colocam, como, por exemplo, a inclusão de perfis locais ou oriundos de classes populares, que ampliariam o 
universo de desaparecidos além das classes médias e dos desaparecimentos ocorridos nas zonas urbanas de Buenos Aires ou La Plata; e a recuperação dos seus compromissos políticos, incluindo a sua afiliação a diversas organizações político-militares e suas redes de militância (CRENZEL, 2010, p. 15-16).

\section{A juventude como alvo da última ditadura civil-militar}

A partir do que foi dito sobre a produção de memórias e representações dos desaparecidos na Argentina pós-ditatorial, em relação aos estudantes secundaristas, notamos que durante a última ditadura civil-militar afirmaram-se como uma categoria de vítimas com forte apelo para rebater os argumentos que legitimavam a guerra subversiva e para denunciar a ilegalidade da violência estatal. Contudo, desde o primeiro momento, a sua opção política ocupou um lugar marginal, já que passou a ser associada a noções de vulnerabilidade e ingenuidade, dadas pela idade; e de baixo grau de politização, voltada a questões escolares e a trabalhos comunitários.

Com o intuito de entendermos tal construção, precisamos analisar o discurso ditatorial voltado para os jovens: eles eram tidos como destinatários privilegiados do legado do Processo de Reorganização Nacional. Desde o comunicado número 13, divulgado no primeiro dia que seguiu ao golpe, a Junta de Comandantes Generais das Forças Armadas convocava os jovens a integrar a comunidade nacional e a contribuir com sua sinceridade, franqueza, entusiasmo e idealismo para a reconstrução da pátria (BLAUSTEIN, 2006, p. 98).

Deveriam assim deixar de lado as práticas que conformaram a partir de meados da década de 1960 uma cultura juvenil, cuja heterogeneidade de formas de expressão coincidia geralmente com um tom crítico à ordem social, política e moral. Ela estava assentada no fato de que suas experiências, gostos e consumos culturais passaram a ser percebidos por eles, pela sociedade, pelo mercado, pelos meios de comunicação e pelos intelectuais como significativos de certa idade; e assumiu traços como a heterogeneidade de referências culturais e intelectuais, acessíveis no marco de uma indústria cultural em crescimento; novas formas de vincular-se entre si e de estabelecer relações afetivas e 
sexuais; a crítica ao sistema e a crença em uma possível mudança estrutural; e a política entendida como um espaço de conflitos (PUJOL, 2003, p. 285 e CATTARUZZA, 2008 e OLLIER, 2009, pp. 16-22).

Consequentemente, a partir da Revolução Argentina, a juventude passou a ser tida como uma configuração sociocultural suspeitosa, causadora da debilidade moral: eram os jovens que atentavam contra os modos de vida compatíveis com a moral ocidental e cristão; que subvertiam os códigos indumentários instituídos pela sociedade; que possuíam hábitos sexuais pervertidos, vivendo seus romances sob a escuridão das praças públicas; e os principais provocadores de conflitos com a autoridade, dentro e fora do ambiente familiar (PUJOL, 2003, p. 314-320). Essa visão acentuou-se a partir do ano de 1969 quando ela se somou ao ciclo de protesto dos trabalhadores industriais em diversas cidades do país, cobrando um protagonismo relevante em uma mobilização que até então havia sido liderada quase que exclusivamente pela classe operária, e legitimando novas formas de se fazer política, dentre as quais estava a luta armada (MANZANO, 2011, p. 41).

Entretanto, durante o período constitucional que a seguiu, de ameaças os jovens passaram a ser tidos como importantes na tarefa de reconstrução nacional então empreendida pelos peronistas. No governo de Héctor J. Cámpora, por exemplo, permitiuse a formação de centros estudantis autorizados nas escolas, locais que não estiveram alheios ao processo de mobilizações. A década de 1960 foi um momento de consolidação do crescimento do corpo estudantil e de questionamento dos estudantes ao autoritarismo escolar e a uma disciplina rígida que sufocava canais de participação, formas de expressão e sensibilidades emergentes. Uma das suas alternativas de organização foi a rearticulação do movimento estudantil, que passou a ser disputada por grupos ligados ao movimento de base de diferentes correntes políticas. ${ }^{6}$ Nesse quadro,

\footnotetext{
${ }^{6}$ De acordo com um dossiê organizado pela Comisión Provincial por la Memoria (CPM), dentre os agrupamentos de secundaristas que respondiam a diferentes extrações políticas da esquerda, podemos citar: a Unión de Estudiantes Secundarios (UES) vinculada a Montoneros, de origem peronista; a Juventud Guevarista (JG), vinculado ao Partido Revolucionario de los Trabajadores), marxista; a Federación Juvenil Comunista, ligada ao Partido Comunista Argentino; a Juventud Socialista do Partido Socialista; o Grupo de estudiantes socialistas antiimperialistas; e a Juventud Radical Revolucionaria do Partido Radical (CPM, 2006, p. 3).
} 
em 1973, o jornal La Opinión editou um suplemento dedicado à análise dos fenômenos políticos entre os adolescentes, no qual constavam os resultados de uma enquete realizada entre 252 estudantes. Ela apontava que 30,3\% dos jovens quando questionados afirmavam que tinham algum tipo de participação política. Sobre sua atitude em relação à guerrilha, apenas $36 \%$ se diziam desfavoráveis, enquanto $54 \%$ dividiam-se entre favoráveis e amistosos a ela (BERGUIER; HECKER; SCHIFRIN, 1986, p. 35-36).

Foram jovens como estes que a última ditadura civil-militar passou a tratar como subversivos. No discurso militar, a natureza do inimigo que a nação e as Forças Armadas deveriam combater era política e ideológica antes que militar: o que deveria ser eliminado era a sua condição subversiva. Apesar de que um dado relevante para identificá-lo era a ideologia marxista ou de esquerda, o subversivo poderia estar dissimulado sob outros disfarces que o permitiam atuar em todos os planos da sociedade, incluindo assim os ativistas que não estavam associados diretamente a ações armadas, considerados os mais eficazes transmissores do vírus subversivo. Um dos seus principais campos de atuação eram os âmbitos educacionais, espreitados desde dentro pela subversão, o que contribuía para o encadeamento ideológico das futuras gerações (CPM, 2006, p. 46 e NOVARO; PALERMO, 2007, p. 115-116).

Em 18 de junho de 1976, a militante montonera Ana María González, de 18 anos, utilizando-se do acesso que tinha à casa do chefe da Polícia Federal Argentina, Cesáreo Cardozo, por ser colega de escola de sua filha, colocou uma bomba embaixo da sua cama, matando-o. Este episódio serviu para construir uma série de imagens acerca dos militantes de organizações armadas, concentradas principalmente nas mulheres e nos jovens de classe média como mais propensos à cooptação da guerrilha: indivíduos entediados, que não se interessavam por nada, para os quais militar em uma organização subversiva era quase um passatempo (LORENZ 2007, pp. 29, 34-39). Por conseguinte, um dos arquétipos construídos em torno dos integrantes das guerrilhas era o de jovens de classe média volúveis, influenciados principalmente pelo marxismo cubano e pelo cristianismo revolucionário.

Assim em 01 de julho de 1976, a revista Gente publicou um editorial assinado por Bernardo Neustadt, no qual ele afirmava que casos como este não seriam uma novidade, 
pois já se sabia da participação de adolescentes em ações armadas. O que impressionava era o fato de serem jovens oriundos das classes médias e altas, filhos da comodidade, cidadãos-descuidados de um mundo sem autoridade, que os levava ao tédio e, em uma minoria potente, ao assassinato por um mundo melhor. ${ }^{7}$ Dois dias depois, em um suplemento especial, perguntaria a dez pais o que eles faziam para evitar que seus filhos se convertessem em guerrilheiros, buscando compreender os motivos que levavam os jovens argentinos à luta armada. As respostas apontavam para o problema de diálogo entre pais e filhos, falhas nas condutas dos pais, a rebeldia inerente dos jovens e novamente o ócio resultante da sua condição socioeconômica. Podemos também perceber nas respostas a demanda por medidas enérgicas que tornassem esse problema em uma questão de governo (Gente, 03/07/1976). ${ }^{8}$

Respondendo a tais anseios, a ditadura desenvolveu duas frentes de ação. A primeira, uma guerra cultural através do desenho de modelos educativos que permitissem ao Ministério de Cultura e Educação recuperá-los e orientá-los. A intervenção sobre os conteúdos e sobre as leituras permitidas; a regulação dos comportamentos e condutas; a ênfase posta na importância dos ritos escolares que exaltavam os valores católicos e nacionais passou a marcar o cotidiano escolar, articulando-se com práticas que já limitavam a mobilização estudantil. ${ }^{9}$ Era cobrado ainda dos pais e do pessoal docente e

7 http://educacionymemoria.educ.ar/secundaria/wp-content/uploads/2011/03/fuentes-capitulo-2.-Pensar-ladictadura.pdf Acesso em 02 setembro 2013.

${ }^{8}$ A revista Gente era a publicação de maior tiragem da Editorial Atlántida. Esta é recordada como uma das empresas midiáticas que apoiou mais explicitamente a última ditadura civil-militar, convertendo suas revistas após o golpe - Gente, Somos e Para Ti -, em espaços de valoração positiva da guerra antisubversiva e da política econômica do Ministro Martínez de Hoz (GATO ; SABORIDO, 2011, p. 337). Assim, podemos observar uma mudança no seu discurso relativo à juventude que então passou a ser apresentada como uma ameaça, enquanto em 30 de outubro de 1975, uma nota publicada em Gente apresentava-a como uma geração maravilhosa, que estudava e trabalhava, que não se calava e questionava, e que se preocupava menos com o exterior e mais com o futuro político do seu país, mudando o seu papel de espectadores a atores da realidade que Ihes tocava viver . Ver: http://educacionymemoria.educ.ar/secundaria/wp-content/uploads/2011/03/fuentes-capitulo-2.-Pensar-ladictadura.pdf Acesso em 02 setembro 2013.

${ }^{9}$ As políticas educativas da última ditadura registraram algumas continuidades em relação a intervenções que a antecederam, principalmente no período em que Oscar Ivanissevich esteve à frente do Ministério da Cultura e Educação. A partir de 1974, a direita peronista, cada vez mais presente na estrutura governamental, assumiu a área da educação, adotando uma postura de limitação ao movimento estudantil e recuperação dos princípios de ordem. Através da Dirección Nacional de Educación Media lançou-se um plano que reincorporava as velhas autoridades afastadas com as mobilizações de 1973, no final da Revolução Argentina, e foi elaborada a Circular $N^{\circ} 12$, limitando o acionar dos centros estudantis, 
diretivo dos colégios que colaborassem nas atividades de suspeição de vigilância, ${ }^{10}$ de forma a garantir a formação dos novos cidadãos argentinos (ALONSO, 2005 e NOVARO; PALERMO, 2007, p. 183-185).

A outra frente de ação foi o sequestro e o desaparecimento de estudantes que desenvolviam tarefas de militância dentro e fora das escolas. Segundo dados da Comisión Nacional sobre la Desaparición de Personas (CONADEP), 250 adolescentes entre 13 e 18 anos foram sequestrados em sete anos de ditadura (NUNCA MÁS, 1984, p. 322). A semelhança entre os casos publicamente conhecidos demonstra que não foram casos isolados ou fruto do acaso, mas operações que buscavam desarticular a militância em determinada instituição através do sequestro de um grupo de estudantes definido previamente, vinculado geralmente ao agrupamento estudantil de alguma organização ou partido político.

Ao associar juventude e subversão, a última ditadura civil-militar argentina pôs em prática o que o então o General de Brigada, Edgardo Vilas, definiu, em 16 de setembro de 1977, como uma guerra cultural e definitiva: “Más que lucha por las armas, es una lucha por las almas Para graficar: se ha podado un árbol y para que no brote en el futuro será necesario quemar la raíz y el tronco de ese árbol”. (GARULLI, 2011, p. 102-3). Galhos podados da árvore da subversão, os desaparecidos só foram nomeados pelos militares em dezembro de 1977 quando, em uma conferência de imprensa, o General Jorge Rafael Videla apontou-os como guerrilheiros, explicando suas ausências pelo estado de guerra, como resultado das práticas próprias da subversão ou como excessos da repressão (CRENZEL, 2008, p. 37). Já as denúncias realizadas no exterior foram questionadas como ficções ou mentiras dos

reimplantando rígidas normas disciplinares e determinando a possível intervenção policial nas escolas. No ano de 1975, a proibição dos centros estudantis foi reimplantada, assim como a intervenção ministeriais das escolas cujas autoridades se mostrassem reticentes em tomar medidas enérgicas para recuperar a autoridade, como a sanção a alunos envolvidos em atividades políticas, impedindo-os de realizar a matrícula no início do ano letivo (BERGUER; HECKER; SCHIFRIN, 1986, p. 2-3; MANZANO, 2011, p. 46).

${ }^{10}$ De acordo com Sergio Pujol, durante o ano de 1976, o chefe da Secretaría de Inteligencia de Estado (SIDE), o general Otto Carlos Paladino, manteve reuniões regulares na Escuela de Educación Técnica № 1 Otto Krause com reitores de distintos colégios de Buenos Aires. Nesse mesmo ano, foi criada uma oficina de Recursos Humanos, ligada ao Ministério, apontada como a responsável por realizar tarefas de espionagem nos colégios estatais e privados e pela elaboração das listas negras através da delação de reitores e docentes a alunos e colegas de trabalho suspeitos (PUJOL, 2011, p. 32, 35). 
delinquentes terroristas derrotados, pois nas listas dos pretendidos desaparecidos figuravam pessoas que haviam passado voluntariamente à clandestinidade ou que se encontravam residindo fora do país. No contexto da visita da Comissão Interamericana de Direitos Humanos (CIDH), o regime adotou um discurso segundo o qual não existiriam desaparecidos, mas mortos não registrados (JENSEN, 2010, p. 63-67, 101,136).

Entretanto, enquanto a ditadura mantinha a sua política de negação e de omissão dos fatos, os desaparecimentos geraram uma mobilização que para muitos se iniciou como uma demanda de índole privada e individual e aos poucos se tornou em um dos principais movimentos de resistência, tanto na Argentina quanto no exterior, através da formação de organismos novos ou de uma mudança nas estratégias e discursos de outros já existentes: o movimento argentino pelos direitos humanos. Resistência esta que se baseou em uma relação entre três componentes: o reclamo pela verdade sobre as violações cometidas; a demanda de justiça e de castigo aos perpetuadores, em uma demonstração de que não ficariam impunes; e o dever de memória contra uma política de esquecimento e de falsificação do ocorrido (JELIN, 1995, p. 104 e VEZZETTI, 2002, p. 2223).

Os organismos de direitos humanos realizaram ações de contenção e apoio aos familiares dos que haviam sido levados, de averiguação de qual fora o seu destino, e de denúncia do ocorrido para tentar interromper a violência. Em suas primeiras denúncias, Emilio Crenzel aponta para um caráter heterogêneo do conhecimento e do reconhecimento da natureza do desaparecimento, que se expressou pincipalmente na incredibilidade aos relatos dos que foram reaparecidos, os sobreviventes dos centros clandestinos de detenção, cujos testemunhos enfrentaram a negação dos que se recusavam em aceitar que seus familiares puderam ter sido assassinados e que se tratava de um crime de autoria do Estado (CRENZEL, 2008, p.43). Paralelamente, houve uma crescente homogeneização no modo de denunciar; segundo Elizabeth Jelin, uma revolução paradigmática: os enfrentamentos não eram mais interpretados em termos de lutas de classes ou de revoluções nacionais, mas como violações aos direitos humanos cuja imagem central era violação da vítima, consequência de uma ação estatal, e não do seu compromisso com um projeto político (JELIN, 2010a, p. 76-77). Logo, os que haviam sido 
levados tornaram-se desaparecidos, recuperados em informes, folhetos e solicitações públicas a partir da referência a seus dados identitários básicos, como a idade e o gênero; por categorias compreensivas, como suas ocupações ou pertencimentos religiosos; pela descrição das circunstâncias dos sequestros; e pelas consequências da violência em termos familiares; ressaltando o caráter indiscriminado da violência do estado terrorista e a inocência de suas vítimas - o conjunto da sociedade civil (CRENZEL, 2008, p. 45).

Em 1982, o Centro de Estudios Legales y Sociales (CELS) publicou seis folhetos nos quais demonstrava a responsabilidade das Forças Armadas na repressão, voltada particularmente para a detenção, desaparição e assassinato de algumas categorias de vítimas, dentre as quais estavam “Adolescentes detenidos-desaparecidos”. Este folheto reuniu a denúncia de 130 adolescentes desaparecidos, um dos aspectos mais dramáticos do sistema utilizado, seja pela idade das vítimas, ou por representarem uma esperança de futuro para a sociedade. Não apresentavam algum perigo, pois nenhum encontrava-se na clandestinidade, realizando atividades normais para as suas idades: cursavam o ensino médio, recém haviam ingressado em uma universidade, trabalhavam, cumpriam com o serviço militar obrigatório. Além disso, não possuíam armas ou qualquer material comprometedor. Ao buscar um denominador comum que explicassem os casos, o CELS aponta que foram jovens que cedo já demonstraram inquietudes e o altruísmo; iniciaram o ativismo aos 13 ou 14 anos, militando em organizações consideradas legais antes do golpe, como a UES, os centros estudantis dos respectivos colégios, as unidades de ajuda nos bairros mais pobres. Podemos observar que a aproximação a grupos político-militares não surgem em seu universo de possibilidades; portanto, conclui que a ditadura buscava tirar de circulação jovens que poderiam se converter em líderes estudantis ao invés de receptáculos passivos de suas doutrinas. ${ }^{11}$

Uma das fontes utilizadas pelo CELS para a produção desse folheto foi a compilação de testemunhos de familiares dos adolescentes desaparecidos. De acordo com Elizabeth Jelin, a linguagem e a imagem idealizada da família constituíram nos últimos anos da ditadura a figura central dos discursos e das práticas do movimento de

\footnotetext{
${ }^{11}$ Versão digital disponível em:

http://www.comisionporlamemoria.org/investigacionyense\%C3\%B1anza/recursos-nochelapices-cels.html Acesso em 29 agosto 2013.
} 
direitos humanos. Denunciavam-se então crimes contra a família, lares mutilados pela irrupção da violência, oriunda apenas das forças de seguranças. E projetavam a imagem de bom filho/a do/a jovem desaparecido/a, resgatando características notáveis, traços de bondade e generosidade, e uma ingenuidade quase infantil, como contra-argumento da suspeita generalizada do por algo será que os levaram (JELIN, 2010a, p. 77). Assim, com o sequestro eles tiveram a sua juventude interrompida pela entrada súbita em um mundo de adultos, da política, dos militares e da violência. Tratava-se de um discurso que colocava em cheque a prédica ditatorial, por questionar as supostas responsabilidades familiares pelo destino desses jovens ${ }^{12}$; por denunciar a sua política de ocultamento e negação; e por subverter alguns dos argumentos utilizados por ela, caracterizando as suas práticas a partir de um novo léxico. Logo: “(...) o que se chamara 'guerra interna' era agora 'a repressão' ou o 'terrorismo de Estado', e os que haviam sido 'subversivos' eram agora chamados de 'militantes', 'jovens idealistas', 'vítimas' e, mais precisamente, 'vítimas inocentes." (NOVARO; PALERMO, 2007, p. 641-642).

\section{O mito das vítimas inocentes}

Com a conjuntura aberta pela Guerra das Malvinas, a ditadura perdeu parte do seu apoio social, e a sociedade argentina pareceu disposta a escutar as denúncias sobre os desaparecidos (CRENZEL, 2008, p. 53). Além disso, a partir de outubro de 1982, os meios de comunicação difundiram intensamente e com um forte traço sensacionalista as exumações de tumbas coletivas, publicaram informes de organismos e declarações de militares relatando episódios da repressão. Os desaparecimentos instalaram-se então

\footnotetext{
${ }^{12}$ No discurso da mais recente ditadura civil-militar, a representação tradicional da família foi utilizada como metáfora para unidade natural da organização social que seria recuperada pela ditadura, após anos de caos e de questionamento às autoridades. A penetração de ideias perigosas em uma família representava assim um perigo para toda a nação; logo, era atribuída aos pais a responsabilidade final de prevenir que seus filhos se convertessem em subversivos. "Você sabe onde está seu filho agora?" foi uma frase utilizada pela publicidade estatal que sintetizou a urgência da tarefa de seguimento e controle realizado pelos militares e que deveria ser assumido pelos pais (JELIN, 2010b, p. 228-230). Tanto em seus discursos como em suas respostas aos pedidos de informação e liberdade de pais de desaparecidos, os militares acusavam-nos de não conhecer a verdade sobre a vida de seus filhos, alegando que a sua criação duvidosa era uma das culpadas por terem se convertido em criminosos (FILC, 1997, p. 58).
} 
como tema central da informação pública, um problema que deveria se resolver e investigar. ${ }^{13}$ Porém colocava-se um obstáculo novo: frente a uma sociedade que pela primeira vez parecia entrar em contato com tais fatos, já não se tratava de trazer à tona o ocorrido, mas favorecer uma seleção de critérios e valores que orientassem um trabalho deliberado de produção da memória da experiência ditatorial em uma nova situação aberta pela transição (VEZZETTI, 2002, p. 23).

Os primeiros a tentar orientar esse trabalho foram os militares. Assim, em abril de 1983, o regime transmitiu em cadeia nacional de televisão o Informe Final de la Junta Militar. Neste manteve-se a imagem de um enfrentamento bélico não convencional contra um inimigo interior, que derivou em erros ou excessos cometidos pelas forças de segurança, a negação do caráter clandestino e sistemático da desaparição de pessoas e a existência de desaparecidos (SALVI, 2009, p. 95-98). Em relação aos jovens, sobretudo adolescentes, cooptados pela guerrilha, afirmava que eles não se encontravam desaparecidos: haviam morrido durante enfrentamentos com as forças de mortes; suicidaram-se para evitar sua captura; ou desertaram, precisando assim ocultar-se tanto das autoridades quanto das bandas guerrilheiras às quais pertenciam. ${ }^{14}$

O Informe final gerou o repúdio do movimento de direitos humanos, e de outros grupos políticos e sociais que se aproximaram da sua luta. Consequentemente, o discurso dos direitos humanos se converteu em central durante a transição para a democracia. Apesar das diferenças entre os organismos, em suas mobilizações convergiam em uma bandeira - Juicio y castigo a todos los culpables (JELIN, 1995, p. 118-119) -, estabelecendo o exercício da justiça retroativa como um marco para a elaboração da experiência ditatorial (VEZZETTI, 2002, pp. 22-23); e contrapondo, de um lado, perpetradores de crimes, e, de outro, vítimas. Dessa forma, o conflito político prévio à ditadura, a militância e a luta

\footnotetext{
${ }^{13}$ Segundo Inés González Bombal, a derrota nas Malvinas resultou em uma quebra de anos de censura oficial e uma consequente renovação dos espaços públicos que se viram então invadidos por revelações acerca do passado recente. Porém, o fato dos meios de comunicação trazerem denúncias, exumações e relatos de violência, não atribuiu um sentido ao ocorrido, contribuindo para a perplexidade social frente à verdade que se mostrava sobre os anos da ditadura, o show de horror. (GONZÁLEZ BOMBAL, 1995, p. 204).

${ }^{14}$ Versão digital disponível em: http://www.memoriaabierta.org.ar/materiales/documento_final_junta.php Acesso em 29 agosto 2013.
} 
armada não estavam no centro da atenção. Tal representação gerou desdobramentos significativos no discurso e na prática do Estado. Por um lado, o governo de Raul Alfonsín afirmou uma interpretação baseada em um cenário de duas forças violentas em luta - os dois demônios. No meio disso, estariam aqueles que queriam a vida democrática: uma maioria supostamente distante e ausente dos conflitos em curso, na qual se situava a maioria de suas vítimas. Por outro, a perseguição judicial aos ex-comandantes - o Juicio a las Juntas - manteve como figura central a vítima da repressão estatal, alheia a ideologias ou a práticas políticas combativas. ${ }^{15}$

Como afirmara Ernesto Sábato na apresentação do Movimento para recuperação de Crianças Desaparecidas, em dezembro de 1981, a imensa maioria dos desaparecidos seriam pessoas escolhidas ao acaso, nomes que constavam em uma agenda apreendida, “(...) inocentes cujo único crime foi terem sido amigos ou colegas de classe de supostos delinquentes." (NOVARO; PALERMO, 2007, p. 641-642). De acordo com Inés González Bombal, nesse momento o desaparecimento foi visto como uma violação a profundos princípios de ordem cultural, mais que especificamente políticos: a sociedade argentina não encontrava razões lógicas que explicassem por que não foram devolvidos os corpos; e a desumanização e a perda de identidade das vítimas eram vistas como uma operação que escapava de todos os limites. O que horroriza e repercutia eram os possíveis equívocos e injustiças irreparáveis cometidos pela repressão. Portanto, a recuperação das vítimas girou em torno principalmente das hipervítimas - adolescentes, crianças, mulheres grávidas, idosos - consideradas fora do admissível (GONZALEZ BOMBAL, 1995, p. 205-207).

\footnotetext{
${ }^{15}$ Segundo esta interpretação, a Argentina esteve submetida à violência política fruto dos extremos ideológicos nos anos prévios ao golpe de Estado de 1976, o que explicaria o caráter assumido pela resposta estatal: ao demônio da violência revolucionária se opôs uma ainda mais condenável no terrorismo de Estado. Logo, a guerrilha seria a única responsável pela violência antes do início da ditadura; já a revisão da metodologia utilizada pelas forças de segurança se centraria no período de 1976 a 1979, tidos como os mais intensos da repressão. Excluía-se assim o exame da intervenção militar durante o governo de Isabel Perón e as condições de adoção das modalidades repressivas. Dois demônios equiparáveis no uso da violência e na culpa pelo desprezo à democracia que, para serem superados, necessitava-se de um ato de justiça que tomasse em conta essa dupla responsabilidade. Para uma discussão sobre a teoria dos dois demônios, ver: VEZZETTI, 2002, p. 37-38, 118-122 e NOVARO; PALERMO, 2007, p. 643-649 e BISQUERT; LVOVICH, 2008, p. 34-37.
} 
Estas vítimas constituíram o que posteriormente tornou-se conhecido como mito das vítimas inocentes. Porém, a ideia de que houve uma vítima inocente respalda implicitamente a tortura, o sequestro e a desaparição daqueles não inocentes: quem participou ativamente da luta armada. Estes inclusive poderiam sofrer sanções penais devido aos atos terroristas cometidos. Em relação aos estudantes secundaristas então perseguidos pela última ditadura, eles encaixavam-se devido ao atributo natural de estarem na adolescência, que os dotava de uma dupla inocência: uma de tipo jurídico, pois por serem menores de idade não eram sujeitos imputáveis por seus atos; outra de tipo simbólica, de uma adolescência associada à pureza e à maior proximidade da infância do que da vida adulta (RAGGIO, 2010, p. 159).

Esta associação encontrou um veículo importante de difusão no relatório final da CONADEP, publicado em novembro de 1984: o Nunca Más. Este deveria conjugar duas intenções: expressar uma condenação moral dos desaparecimentos e constituir-se como um legado para o futuro que ajudaria a evitar uma nova experiência de violência. Ganharam destaque em suas páginas os casos que demonstravam que dentro do delírio semântico, tudo era possível; proposição que ao mesmo tempo em que distanciava o exercício do terror de qualquer racionalidade, propunha uma imagem vasta e imprevisível de que poderiam ser suas vítimas (NUNCA MÁS, 1986, p. 9-10). Dentre as vítimas desamparadas sob o terror estatal estavam adolescentes sensíveis que, apesar das trajetórias pessoais distintas, tinham alguns traços em comum: a ingenuidade, a sensibilidade, e o repúdio à injustiça, à hipocrisia e à impossibilidade de mudanças. Aponta que a maioria fora sequestrada na casa de familiares, à noite, com forte demonstração de violência. O testemunho dos liberados, uma das quatro categorias que compunha o universo de vítimas adolescentes, apontava que o tratamento recebido nos centros clandestinos de detenção e a tortura foram os mesmos para adultos e adolescentes, independentemente de sua idade (NUNCA MÁS, 1986, p. 329-335).

Dentre os casos citados na página do Nunca Más de sequestro e desaparecimento de estudantes secundaristas, estava a tristemente recordada em La Plata como "Noche de lo lápices". As conclusões da CONADEP apontaram para uma possível matança de adolescentes-estudantes secundaristas, devido à campanha realizada na cidade de La Plata 
pelo boleto estudantil secundarista (BES), em 1975, da qual participaram os sete jovens então associados ao caso, e apontada como o único elemento comum em suas histórias antes do sequestro, em detrimento da sua militância em agrupamentos estudantis ligados à estrutura de organizações político-militares de esquerda. Essa versão teria se conformado a partir da reunião de testemunhos, dentre os quais estava o de Pablo Díaz, um dos sobreviventes do episódio. Entretanto, o seu testemunho encontrou limites para recuperar a sua militância e a dos jovens desaparecidos: este se baseou na sua memória corporal, e do reconhecimento de outros detidos, guardas, torturadores ou chefes militares. Contudo, ele provavelmente não foi questionado sobre suas escolhas políticas; e os sobreviventes, em sua grande maioria, devido ao instável contexto político, ao juízo que se fazia em relação ao compromisso políticos na década de 1970 e às causas judiciais abertas contra membro da guerrilha, omitiram-nas. (CRENZE, 2008, p. 72). Logo, de acordo com Pablo Díaz, para assegurar a sua inclusão entre os inocentes, o seu relato encontrou na luta pelo BES uma explicação para os desaparecimentos (LORENZ, 2007, p. 59-60).

De acordo com Sandra Raggio, a partir de então o episódio passou a ser conhecido como La noche de los lápices e, ao receber esse nome, inseria-se o ocorrido em um trama que, ao destacar certos elementos, demonstrava de que maneira tais fatos foram percebidos e significados nos primeiros anos da democracia, baseando-se na intenção de se denunciar um sucesso trágico, com forte conotação negativa, e obliterando-se a militância dos jovens em detrimento à sua categoria sócio-ocupacional: "'La noche de los lápices', además de ofrecer una metáfora - muy usada- para hablar del período de la dictadura, refiere a 'una particular': la del 16 de septiembre. Los 'lápices' aluden a los protagonistas de esta historia: las víctimas: todos ellos estudiantes secundarios." (RAGGIO, 2005, p. 100).

A inocência das vítimas da última ditadura, e os consequentes limites que essa representação trazia ao testemunho dos sobreviventes, foram reafirmados durante o Juicio a las Juntas, iniciado em abril de 1985. Em suas sessões, dos 8.000 casos reunidos e remetidos pela CONADEP à Justiça, foram selecionados cerca de 800, tanto por razão de economia processual, para assegurar o andamento do julgamento, como por suas 
qualidades de provar que a repressão teria sido parte de um plano sistemático e organizado desde o Estado, cuja responsabilidade imediata seria dos membros das três Juntas militares. Somaram-se a estes os casos mais fortes, cuja escolha justificava-se no propósito de demonstrar as contradições que expunham o discurso ditatorial, principalmente acerca das supostas ameaças subversivas e da proteção da família argentina (MEMORIA ABIERTA, 2010, p. 80-84).

Ao longo do Juicio, a Editora Perfil lançou uma publicação semanal destinada a informar sobre as sessões e a publicar as transcrições dos testemunhos a partir de um critério de representatividade, com a função de provar a ação do terrorismo de Estado (FELD, 2002, p. 25-32), dentre os quais se encontram os testemunhos de alguns sobreviventes, estudantes secundaristas sequestrados, nos quais todos omitem a sua participação em agrupamentos estudantis, apontando que a sua militância teria se restringido à participação em centros de estudantes nos colégios onde estudaram. Dentre esses testemunhos, encontram-se o de Pablo Díaz, no qual ele reforça a versão de que o seu sequestro e dos outros estudantes platenses foi resultado do seu envolvimento no pedido do BES no ano anterior (DIARIO DEL JUICIO, 1985, n.3, p. 62-63). Já Alejandra Naftal, sequestrada em 09 de maio de 1978, aos 17 anos, relata que, quando questionada por um dos seus torturadores no centro clandestinos de detenção El Vesubio por que estava ali se ainda era uma menina, ao dizer que estudava na Escuela Superior de Comercio Carlos Pellegrini, este afirmou que tinha certeza que seu caso era assunto do colégio (DIARIO DEL JUICIO, 1985, n.15, p. 334-336).

\section{Juventude e militância}

Podemos perceber que, nos primeiros anos da democracia, em um momento em que se formulava um juízo negativo em relação aos métodos violentos utilizados tanto pela ditadura quanto pelas organizações político-militares da esquerda, casos como o dos estudantes secundaristas sequestrados e desaparecidos tiveram uma importância na denúncia às violações dos direitos humanos cometidas pelo terrorismo de Estado. A violência desenfreada contra pessoas comuns aleatoriamente gerava uma identificação 
direta com uma sociedade que naquele momento optara por se identificar emocionalmente com os dramas familiares das vítimas ao invés de realizar um questionamento sobre as suas atitudes e omissões durante a ditadura. Construíam assim uma visão retrospectiva do seu apoio às medidas enérgicas do regime, como se estas apenas se justificassem caso direcionadas aos subversivos envolvidos na luta armada.

Nesse marco, repercutiu principalmente casos como o dos jovens de la noche de los lápices, que concentrava elementos significativos que justificavam a inclusão de alguns dos desaparecidos entre as vítimas inocentes: “(...) adolescentes frente a los adultos que los reprimen (aún estaban estudiando) por un reclamo 'apolítico' de carácter gremial (el boleto secundario), que pocos considerarían injusto o inadecuado (...).”(LORENZ, 2007, p. 57). Consequentemente, a memória produzida sobre os estudantes secundaristas desaparecidos restringiu as suas práticas a reclames próprios de sua categoria e a uma sensibilidade particular que não estariam marcados por um contexto social e cultural de uma época, mas pela sua naturalização como constituintes de certa subjetividade adolescente que correspondia a uma imagem de juventude que coincide com o senso comum - desprendimento, ímpeto, questionamento, idealismo (SARLO, 2007, p. 56).

A partir da década de 1990, notamos a recuperação da militância dos desaparecidos no discurso de alguns setores do movimento pelos direitos humanos, principalmente as Madres de Plaza de Mayo: as até então vítimas - cidadãos cujos direitos fundamentais, principalmente a vida, haviam sido arrasados - passaram a ser representados como militantes populares. De acordo com Elizabeth Jelin, o que se tornou visível foi o comprometimento dos desaparecidos como uma militância social, baseada em princípios humanistas, geralmente cristãos, de ajuda aos pobres para uma melhoria de sua condição social: "Sea como activismo social (más facilmente aceptado) o como activismo político en pos de un ideal de justicia social, tímidamente comienzan a aparecer figuras de víctimas con voluntad política. El uso de las armas todavía quedaba en las sombras, en el silencio..." (JELIN, 2010a, p. 78).

Paralelamente, os testemunhos cobraram autonomia da meta punitiva, trazendo para a cena pública memórias militantes através de filmes, documentários e novelas testemunhais, que confrontavam diretamente a versão que ocultava através do 
paradigma da inocência a militância dos desaparecidos Estas memórias até então se encontravam silenciadas devido à estigmatização ditatorial dos compromissos políticos subversivos e à perseguição penal da qual foram objeto os membros da guerrilha até a assinatura das Leis de Indulto. ${ }^{16}$ Porém, elas ressaltavam os ideais da militância e seu compromisso com a mudança social, excluindo a crítica da violência política. Além disso, não resultou em uma mudança significativa na recuperação dos desaparecidos que continuaram se baseando nos relatos de caráter íntimo, familiar e privado (CRENZEL, 2011, p. 280).

Em relação ao episódio La noche de los lápices, por exemplo, outros sobreviventes vinculados ao episódio, Emilce Moler e Gustavo Calloti, tornaram públicos seus testemunhos nos quais, além de se reafirmarem como sobreviventes desse operativo, problematizam a versão consagrada pelo livro, ao ressaltarem que os estudantes detenidos-desaparecidos eram todos militantes políticos que possuíam um projeto que ia além da luta pelo BES, para eles uma construção posterior que visava sensibilizar a sociedade sobre até que extremo chegou a ditadura. Esses testemunhos podem ser vistos, por exemplo, em dois documentários, Los irrecuperables (2006) e El boleto fue secundario (2009), iniciativas de outros atores que buscaram novas formas de narrar uma história que lhes fora transmitida, que se encontrava consagrada em sua memória, mas cuja versão lhes parecia insatisfatória.

Além disso, em 2001, Jorge Falcone, irmão de María Claudia Falcone, publicou um livro de memórias no qual relata o sequestro de sua irmã de uma maneira distinta da consagrada. Em um breve capítulo, ele relata que María Claudia e María Clara Ciocchini teriam sido interceptadas pelas forças repressivas quando entravam no hall do edifício do

\footnotetext{
${ }^{16}$ Os primeiros Indultos, assinados em 07 de outubro de 1989, incluíam cerca de 300 pessoas com processo judicial aberto, de acordo com quatro situações: altos chefes militares processados e que não foram beneficiados pelas leis de Punto Final e de Obediencia Debida; acusados de subversão, que se encontravam prófugos, detidos, encarcerados ou condenados; alguns repressores pertencentes às forças de segurança uruguaia; os envolvidos nos levantes carapintadas; ex membros da última Junta Militar que haviam sido condenados por suas responsabilidades na Guerra das Malvinas - tenente general Leopoldo Fortunato Galtieri, almirante Jorge Isaac Anaya e brigadeiro general Basilio Arturo Ignacio Lami Dozo. No ano seguinte, em 30 de dezembro de 1990, Menem ditou outros decretos que indultavam boa parte dos membros das forças repressoras e os dirigentes das organizações político -militares que haviam sido condenados, e alguns militares que ainda esperavam sentenças judiciais (MEMORIA ABIERTA, 2010, p. 97).
} 
apartamento da tia da primeira. Era meia-noite e as duas jovens voltavam de uma busca mal sucedida por um local mais seguro para dormirem. Elas estariam armadas e, apesar de não terem iniciado um tiroteio, tentaram resistir à captura. Finalmente são encurraladas no apartamento da tia, no qual os agentes repressivos encontraram armas escondidas. (FALCONE, 2001, p.82-84). Esta cena difere muito da veiculada pelo livro, na qual as jovens são surpreendidas dormindo, totalmente indefesas e cujas preocupações anteriores eram apenas aquelas consideradas naturais à sua idade: amores juvenis em curso.

Tais mudanças e permanências puderam ser notadas nas homenagens realizadas em colégios e escolas, realizadas geralmente por comissões de memórias, voltadas a recuperar os nomes e as biografias de ex-alunos desaparecidos, prática comum a partir do boom das memórias da ditadura no vigésimo aniversário do golpe (Da Silva CATELA, 2001, p. 225-227, 276-277). ${ }^{17}$ Como afirmamos anteriormente, essas práticas tornaram-se comuns no mês de setembro, tendo como mote a comemoração de mais um aniversário do episódio conhecido como La noche de los Lápices. É interessante notarmos que, além de se constituir como uma porta de entrada de muitos estudantes argentinos à questão dos desaparecidos, esse episódio tornou-se o propulsor da recuperação de outras memórias e episódios similares. De acordo com Ludmila da Silva Catela, alguns casos emblemáticos da repressão ditatorial são utilizados para se referir sinteticamente a casos similares, principalmente no que diz respeito ao perfil do atingidos (Da SILVA CATELA, 2001, p. 80-81). Pensando nisso, Sandra Raggio aponta que aconteceria isso com La noche de los lápices, tornando-o uma metonímia de casos análogos de estudantes desaparecidos (RAGGIO, 2005, p. 99). Metonímia esta que encontra nas homenagens de setembro o seu principal momento de afirmação.

\footnotetext{
${ }^{17}$ A aproximação do aniversário de vinte anos do golpe e o surgimento da agrupação H.I.J.O.S. (Hijos por la Identidad y la Justicia contra el Olvido y el Silencio) na cena pública argentina marcaram uma inflexão nos debates sobre a memória da mais recente ditadura civil-militar. Às tradicionais vozes da busca pela verdade e pela preservação da memória, somaram-se os filhos dos desaparecidos políticos que colocaram novos questionamentos sobre as identidades políticas dos seus pais. Começaram a aparecer também as confissões e autocríticas públicas de torturadores, executores e chefes militares, constituindo assim um boom da memória nos meios de comunicação.
} 
Em 16 de setembro de 1996, por exemplo, o Consejo Deliberante da cidade de Buenos Aires aprovou com unanimidade a inauguração de uma placa em homenagem aos 105 desaparecidos do Colegio Nacional, na qual se inscreveu a frase: "Vano el intento de la noche, los lápices siguen escribiendo". Esta inscrição surgira anonimamente nas paredes do Colegio Otto Krause, localizado nas imediações das instalações onde funcionara a ESMA, em 1986, e rapidamente foi capitalizada como lema do movimento estudantil secundarista em Buenos Aires, em um demonstrativo de que a memória dos estudantes de La Plata continuaria sendo transmitida apesar da tentativa de esquecimento da ditadura. Apesar dessa associação direta com um caso que afirmava a inocência dos adolescentes desaparecidos, na inauguração da placa discursou um ex-aluno, Enrique Vázquez, que questionou o silêncio imposto pela centralidade do mito das vítimas inocentes à militância dos seus antigos companheiros então homenageados:

Durante estos años nos resultó complicado llamar las cosas por su nombre (...) Durante mucho tiempo pareció más conveniente -o más presentable, (...)- decir que los estudiantes desaparecidos luchaban por el boleto estudiantil y diluir sus anhelos revolucionarios en pequeñas demandas gremiales. Era como si reivindicar su militancia los hiciera menos inocentes, menos defendibles (...) Sin embargo, nuestros compañeros eran, soñaban con ser subversivos (CHÁVEZ; LEWINGER, 1998, p. 245).

Já em 16 de setembro de 1998, na Escuela Comercial Carlos Pellegrini, realizou-se uma homenagem aos 34 ex alunos e 2 docentes desaparecidos, na qual foi ampliada uma placa já existente com apenas 07 nomes. Durante a inauguração, alunos carregaram pacartas com fotos de cada um deles, a maioria fotos de relatórios escolares, nos quais eles se encontravam vestidos com os blazers do uniforme. Um dos discursos realizados foi o de José Luiz Calvo, ex-aluno do Pellegrini, no qual se identificou como ex-militante da UES no estabelecimento. No entanto, quando falou da militância dos seus excompanheiros caracterizou-a com palavras com uma carga simbólica menor do que as utilizadas por Enrique Vázquez, aproximando-se mais de uma recordação íntima e da recuperação de práticas que seriam comuns à adolescência:

Pero eran como ustedes, como somos todos, con sus más y sus menos, vagos y tragas, seductores y tímidos, divertidos y tristes. Tan capaces de quedarse guitarreando hasta el amanecer, como dedicar el tiempo que les quedaba del estudio a pintar escuelas o ayudar en villas. Eran 
compañeros que en este colegio habían luchado por una consigna que era: libertad de expresión y circulación, que eran expulsados por querer organizar el Centro de Estudiantes o los cuerpos de delegados, que los suspendían por tener el pelo largo o la pollera corta, o por pensar y decir algo diferente a lo permitido en clase. Decían sobre la desigualdad, la injusticia, la falta de libertad. Eran pibes y pibas que pintaban con tizón en las paredes de las escaleras " fuera la policía del colegio", cuando los celadores eran de Coordinación Federal. Eran futboleros, mejores promedios, atorrantes, sensibles, intelectuales, chiquilines. Eran amantes de Los Beatles, de Sui Generis, de Mercedes Sosa. Eran muchas cosas y por sobre todo eran nuestros compañeros, nuestros amigos y amigas, novias y novios. ${ }^{18}$

Doze anos depois, em 16 de setembro de 2010, essa mesma iniciativa resultou na realização de um documentário que trouxe uma discussão acerca da participação política dos ex-alunos do Pellegrini. "Ese acto fue muy flerte. Todos sentimos que de alguna manera los chicos vivieron, crecieron y no pudieron terminar de crecer. Pero también es el lugar donde aprendieron a amar y a militar. En este marco comenzó a prosperar Flores [de septiembre].", com esta frase Ruben Rata, ex-aluno e ex-preceptor da instituição, e um dos realizadores do filme, aponta que houve uma relação entre as duas iniciativas. Porém, Flores de septiembre busca abordar a presença das organizações político-armadas no ambiente escolar, principalmente a relação entre militantes da UES e Montoneros. A conivência entre o político e o pessoal na vida dos jovens é demonstrada através da trajetória de Rubén Benchoam, assassinado em 25 de julho de 1977:

Es el caso de Rubén, que a los 17 años pasó a tener un rol protagónico en la organización y que por un lado sufría la presión de sus superiores que necesitaban subordinación de los militantes y por otro, tenía a sus amigos que planteaban la necesidad de correrse cuando comenzaron las desapariciones. Y él quedó ahí en el medio, en una situación de soledad absoluta. Ese militante orgánico, que debía tomar decisiones tan adultas a la vez recién estaba saliendo de la adolescencia, tenía sueños, amigos, amores, escuchaba Spinetta y le gustaba el helado de frutilla (http://www.diasdehistoria.com.ar/content/el-pellegrini-memorias-deuna-escuela-durante-la-dictadura Acesso em 31 agosto 2013).

Podemos perceber a partir desses discursos que aos poucos a vinculação entre militância e juventude tornou-se presente em iniciativas de recuperação da memória de estudantes secundaristas desaparecidos na última ditadura civil-militar. Recuperou-se

\footnotetext{
18 http://memoriastierra.blogspot.com.br/2011/08/tus-companeros-de-colegio-pueden.html Acesso 31 de agosto 2013.
} 
também a inserção de escolas e colégios secundaristas em um processo mais amplo de mobilizações, o qual foi respondido pela adoção de medidas repressivas específicas. Contudo, trata-se de uma representação que ainda encontra limites na Argentina, principalmente devido às sombras que o mito das vítimas inocentes projeta sob a produção de memórias que gerem uma discussão acerca das escolhas e práticas políticas dos desaparecidos:

(...) esas interpretaciones tienen todavía hoy en la Argentina una presencia fantasmal que proyecta sus sombras sobre los sujetos involucrados y libera sus efectos en nuestra cultura contemporánea. Sombras de guerras pasadas que se hacen presentes e invitan a volver a vivir la situación de pérdida una y otra vez, impidiendo que el trabajo del duelo desemboque en la elaboración (...) La herencia de la dictadura dejó en la memoria colectiva e individual figuras de muerte y de desaparición de las cuales no es posibles desprendernos. Sin embargo, las preguntas acerca de las prácticas y propuestas políticas de quiénes optaron explícitamente por la violencia armada no deberían quedar sepultadas bajo los escombros que produce la sobreexigencia del duelo. (OBERTI, 2006, p. 103, 105).

No ano de 2011, tivemos a oportunidade de assistir aos atos de comemoração do 16 de setembro na cidade de Buenos Aires. Neste dia, em comemoração aos 35 anos de La noche de los lápices, a comunidade escolar do Pellegrini e os familiares dos desaparecidos que ali estudaram e trabalharam colocaram quatro baldosas na rua em frente à escola. Trata-se atualmente de uma das práticas comuns na cidade de Buenos Aires para homenagear e preservar a memória dos desaparecidos na cidade, através da colocação de placas em distintos bairros porteños, marcando domicílios ou lugares em que eles viveram, estudaram, trabalharam ou militaram. As baldosas por la memoria são uma forma de intervenção urbana organizada pelo coletivo Barrios por la memoria y justicia que aborda às pessoas que passam por estes lugares para mostrar-lhes que os desaparecidos poderiam fazer parte do seu entorno: eram vizinhos do bairro, logo seu desaparecimento não ocorrera em uma realidade alheia à sua. Além do trabalho estético com azulejos, geralmente as baldosas reúnem informações recorrentes: nomes dos desaparecidos e datas dos desaparecimentos; a demarcação do que ele fazia no local; e a sua enunciação como militantes populares detenidos-desaparecidos ou assassinados pela ditadura.

Enquanto a prática de homenagem escolhida no Pellegrini colocava a militância como um dos elementos que constituía a identidade dos desaparecidos, os discursos dos atores envolvidos na inauguração evocaram os estudantes desaparecidos sempre como 
jovens idealistas que lutaram por um mundo melhor. Assim, na fala do responsável pelo projeto de Barrios por la Memoria, sua militância é apenas recuperada como parte dos sonhos dos jovens desaparecidos. Uma significação parecida se repetiu na fala de uma das estudantes da instituição, que reivindicou a luta dos seus colegas desaparecidos, militantes setentistas, companheiros que lutaram pela busca de um mundo melhor. Já o reitor da instituição, Marcelo Roitbarg, reivindicou a qualidade humana dos militantes e os sacrifícios que fizeram, apesar dos erros, na busca de um futuro mais digno e de um país mais justo (Página/12, 17/09/2011). Além disso, estabeleceu uma relação direta entre os homenageados do Pellegrini e os jovens de La noche de los lápices, reivindicados por ele como inocentes: "Recordamos a esas víctimas inocentes que pensaban, defendían sus ideas, tenían esperanzas de un mundo mejor y clamaban por justicia social (...)". ${ }^{19}$

Se o 16 de setembro é a data da memória dos estudantes secundaristas desaparecidos, nessa memória não parece haver uma reflexão acerca das suas possibilidades de escolhas políticas em um cenário de mobilização e de confrontação de projetos distintos. Em contrapartida, o que percebemos é o resgate de elementos positivos, valores essenciais deixados pelos desaparecidos que se opõem à crueldade e à violência do sequestro seguido de desaparecimento, reforçando a injustiça vivida por eles e por seus familiares. Todos os relatos não nos permitem compreender o porquê de eles terem se tornado vítimas da mais recente ditadura civil-militar argentina, restringindo-se a uma ideia de injustiça, cujo núcleo se concentra em uma representação que tem como reivindicações centrais a sua vitimização e a recuperação como indivíduos inteligentes, sensíveis, amorosos, e, acima de tudo, jovens.

\section{Referencias}

ACUÑA, Carlos. H.; SMULOVITZ, Catalina. Militares en la transición argentina: del gobierno a la insubordinación constitucional. In: AA.VV. Juicio, castigo y memoria. Derechos Humanos y justicia en la política argentina. Buenos Aires, Nueva Visión, 1995. p. 19-99.

\footnotetext{
${ }^{19}$ http://www.cpel.uba.ar/nota.php?idnota=7\&sec=40 Acesso em 30 agosto 2013.
} 
ALONSO, Fabiana. El combate contra el enemigo interno en la educación pública santafesina durante la última dictadura militar (1976-1983)". In: Anales de las Jornadas Interescuelas, X, 2005, Rosario.

ALTAMIRANO, Carlos. “Pasado presente”. In: CRESPO, Horacio; LIDA, Clara E.; YANKELEVICH, Pablo (Comps.). Argentina, 1976: estudios en torno al golpe de Estado. Buenos Aires: Fondo de Cultura Económica, 2008. p. 17-33.

BERGUIER, Rubén.; HECKER, Eduardo.; SCHIFRIN, Ariel. Estudiantes secundarios, sociedad y política. Buenos Aires: Centro Editor de América Latina, 1986.

BISQUERT, Jaquelina; LVOVICH, Daniel. La cambiante memoria de la dictadura: discursos públicos, movimientos sociales y legitimidad democrática. Buenos Aires: Biblioteca Nacional, 2008

BLAUSTEIN, Eduardo. Decíamos ayer: la prensa argentina bajo el Proceso. Buenos Aires: Colihue, 2006.

BRUZZONE, Gustavo; LONGONI, Ana. (comps.). El siluetazo. Buenos Aires: Adriana Hidalgo Ed., 2008.

CALVEIRO, Pilar. Poder y desaparición: los campos de concentración en Argentina. Buenos Aires: Colihue, 2008.

CATTARUZZA, Alejandro. El mundo por hacer. Una propuesta para el análisis de la cultura juvenil en la Argentina de los años setenta. In: AA.VV. Lucha Armada. Buenos Aires: Ejercitar la memoria editores, n.10, 2008.

CENTRO DE ESTUDIOS LEGALES Y SOCIALES. Adolescentes detenidos-desaparecidos. Buenos Aires: CELS, 1982. Diponível em:

http://www.comisionporlamemoria.org/investigacionyense\%C3\%B1anza/recursosnochelapices-cels.html. Acesso em: 29 agosto 2013.

CHAVEZ, Gonzalo; LEWINGER, Jorge. Los del 73. Memoria Montonera. La Plata: Editorial de la Campana, 1998.

CRENZEL, Emilio. La historia política del Nunca Más. La memoria de las desapariciones en la Argentina. Siglo XXI, Buenos Aires, 2008.

CRENZEL, Emilio. "Memorias y representaciones de los desaparecidos en la Argentina, 1983-2008”. In: CRENZEL, Emilio (Coord.). Los desaparecidos en la Argentina: memorias, representaciones e ideas: 1983-2008. Buenos Aires: Biblos, 2010. p. 11-23. 
CRENZEL, Emilio. "La memoria de los desaparecidos en Argentina”. In: Andreozzi, Gabriele (Coord.). Los juicios por los crímenes de lesa humanidad en Argentina. Buenos Aires: Atuel, 2011. p. 267-286.

CPM - COMISIÓN PROVINCIAL POR LA MEMORIA. Memorias en las aulas. La educación durante la dictadura I. La Plata: CPM, 2006.

Da Silva CATELA, Ludmila. Situação limite e memória: a reconstrução do mundo dos familiares de desaparecidos da Argentina. São Paulo: Hucitec, 2001.

Da Silva CATELA, Ludmila. “Apagón en el Ingenio, escrache en el Museo. Tensiones y disputas entre memorias locales y memorias oficiales en torno a un episodio de represión del 1976". In: Del PINO, Pociano \& JELIN, Elizabeth. Luchas locales, comunidades e identidades. Buenos Aires: Siglo XXI, 2003. p. 63-106.

DIARIO DEL JUICIO. Buenos Aires: Editorial Perfil, 1985.

EL BOLETO fue secundario. Direção: Federico Tartara, Ignacio Alvarez, Julián Carabaial, Luciano Tejada. Argentina, 2009.

FALCONE, Jorge. Memoria de Guerralarga. Un pibe entre cientos de miles. La Plata: Editorial de La Campana, 2011.

FELD, Claudia. Del estrado a la pantalla: las imágenes del juicio a los ex comandantes en Argentina. Buenos Aires: Siglo XXI Ed., 2002.

FILC, Judith. Entre el parentesco y la política. Familia y dictadura, 1976-1983. Buenos Aires: Biblos, 1997.

FLORES de septiembre. Direção: Nicolás Wianszelbaum, Pablo Osores, Roberto Testa. Argentina, 2003.

FRANCO, Marina. "Huecos de la memoria y silencios políticos". In: ANDREOZZI, Gabriele (Coord.). Los juicios por los crímenes de lesa humanidad en Argentina. Buenos Aires: Atuel, 2011. p. 253-265.

FRANCO, Marina. Un enemigo para la nación: orden interna, violencia y "subversión”, 19731976. Buenos Aires: Fondo de Cultura Económica, 2012.

FRANCO, Marina.; LEVÍN, Florencia. "El pasado cercano en clave historiográfica”. In: Franco, Marina; LEVÍN, Florencia. Historia reciente: perspectivas y desafíos para un campo en construcción. Buenos Aires: Paidós, 2007. p. 31-65. 
GAGO, María Paula; SABORIDO, Jorge. "Somos y Gente frente a la guerra de Malvinas: dos miradas en una misma editorial”. In: BORRELLI, Hernán; SABORIDO, Jorge. Voces y silencios: la prensa argentina y la dictadura militar 1976-1983. Buenos Aires: Eudeba 2011. p. 335-358.

GARULLI. Diana. Dictadura (1976-1983): Testimonios y documentos. Buenos Aires: Eudeba, 2011.

GONZÁLEZ BOMBAL, Inés. “"Nunca más': el juicio mas allá de los estrados”. In: AA.VV.. Juicio, castigo y memoria. Derechos Humanos y justicia en la política argentina. Buenos Aires, Nueva Visión, 1995. p. 193-216.

INFORME al día para entender a los jóvenes de hoy. Gente, Buenos Aires, 30 outubro 1975. Disponível em: http://educacionymemoria.educ.ar/secundaria/wpcontent/uploads/2011/03/fuentes-capitulo-2.-Pensar-la-dictadura.pdf Acesso em: 02 set. 2013.

JELIN, Elizabeth. "La política de la memoria: el movimiento de los derechos humanos y la construcción democrática en la Argentina”. In: AA.VV. Juicio, castigo y memoria. Derechos humanos y justicia en la política argentina. Buenos Aires: Nueva Visión, 1995. p. 101-146.

JELIN, Elizabeth. Los trabajos de la memoria. Buenos Aires: Siglo XXI, 2002.

JELIN, Elizabeth. Militantes y combatientes en la historia de las memorias: silencios, denuncias y reivindicaciones. In: AA.VV. Lucha Armada en la Argentina. Anuario 2010. Buenos Aires: Ejercitar la memoria, 2010a. p. 70-83.

JELIN, Elizabeth. “¿Víctimas, familiares o ciudadano/as? Las luchas por la legitimidad de la palabra”. In: CRENZEL, E. Los desaparecidos en la Argentina: memorias, representaciones e ideas: 1983-2008. Buenos Aires: Biblos, 2010b. p. 227-249.

JENSEN, Silvina. Los exiliados. La lucha por los derechos humanos durante la dictadura. Buenos Aires: Sudamericana, 2010.

KAUFMAN, Alejandro. La pregunta por lo acontecido. Ensayos de anamnseis en el presente argentino. Lanús: Ediciones La Cebra, 2012.

LA NOCHE de los lápices. Direção: Héctor Oliveira. Argentina, 1986.

LORENZ, Federico. Combates por la memoria: huellas de la dictadura en la historia. Buenos Aires: Capital Intelectual, 2007.

LOS IRRECUPERABLES. Direção: Ingrid Jaschek, Diego Díaz. Argentina, 2006. 
MANZANO, Valeria. "Cultura, política y movimiento secundario en la Argentina de la segunda mitad del siglo XX”. In: Propuesta Educativa. Buenos Aires: Flacso, n. 35, p. 41-52, jun 2011.

MEMORIA ABIERTA. Abogados, derecho y política. Buenos Aires: Memoria Abierta, 2010.

NEUSTADT, Bernardo. “¿Se preguntó usted cuántas Ana Marías González hay?” Gente, Buenos Aires, 1 jul. 1976. Disponível em:

http://educacionymemoria.educ.ar/secundaria/wp-content/uploads/2011/03/fuentescapitulo-2.-Pensar-la-dictadura.pdf Acesso em: 02 set. 2013.

NEUSTADT, Bernardo. “QQué hace usted para que su hijo no sea guerrillero?” Gente, Buenos Aires, 03 jul.1976, p. 8-11.

NOVARO, Marco; PALERMO, Vicente. A Ditadura Militar Argentina 1976-1983: Do Golpe de Estado à Restauração Democrática. São Paulo: EDUSP, 2007.

NUNCA MÁS. Informe de la Comisión Nacional sobre la Desaparición de Personas. Buenos Aires: EUDEBA, 1986.

OBERTI, Alejandra. "La memoria y sus sombras". In: JELIN, Elizabeth \& KAUFMAN, Susana G. (Comps.). Subjetividad y figuras de la memoria. Buenos Aires: Siglo XXI, 2006. p. 73-109.

OLLIER, María Matilde. De la revolución a la democracia: cambios privados, públicos y políticos de la izquierda argentina. Buenos Aires: Siglo XXI, 2009.

PELLEGRINI memorias de una escuela durante la dictadura. Diario Tiempo Argentino, Buenos Aires, 16 setembro 2010. Disponível em:

http://www.diasdehistoria.com.ar/content/el-pellegrini-memorias-de-una-escuela-durantela-dictadura Acesso em: 31 agosto 2013.

PITTALUGA, Roberto. "Notas sobre la historia del pasado reciente”. In: CERNADAS, Jorge \& LVOVICH, Daniel (Comps.). Historia ¿para qué?: revisitas a una vieja pregunta. Buenos Aires: Promete, 2010. p. 119-143.

PUJOL, Sergio. “Rebeldes y modernos. Una cultura de los jóvenes”. In: JAMES, Daniel. Nueva historia argentina: violencia, proscripción y autoritarismo 1955-1976. Buenos Aires: Sudamericana, 2003. p. 281-328.

PUJOL, Sergio. Rock y dictadura. Crónica de una generación (1976-1983). Buenos Aires: Broket, 2011. 
QUADRAT, Samantha. Viz.; ROLLEMBERG, Denise. “Apresentação”. In: QUADRAT, Samantha Viz; ROLLEMBERG, Denise (Orgs.). A construção social dos regimes autoritários. Legitimidade, consenso e consentimento no século XX. Brasil e América Latina. Rio de Janeiro: Civilização Brasileira, 2010. p. 11-32.

RABOTNIKOF, Nora. “Memoria y política a treinta años del golpe”. In: CRESPO, Horacio; LIDA, Clara E.; YANKELEVICH, Pablo (Comps.). Argentina, 1976: estudios en torno al golpe de Estado. Buenos Aires: Fondo de Cultura Económica, 2008. p. 17-33.

RAGGIO, Sandra. "Narrar el terrorismo de Estado. De los hechos a la denuncia pública: el caso de 'la noche de los lápices”'. In: Cuadernos del CISH. La Plata: UNLP, n. 17-18, p. 99-125, 2005.

RAGGIO, Sandra. "La noche de los lápices: del testimonio judicial al relato cinematográfico". In: FELD, Claudia; MOR, Jesica Stites (Comps.). El pasado que miramos: memoria e imagen ante la historia reciente. Buenos Aires: Paidos, 2009. p. 45-76.

RAGGIO, Sandra. "La construcción de un relato emblemático de la represión: la 'noche de los lápices"”. In: CRENZEL, Emilio (coord.). Los desaparecidos en la Argentina: memorias, representaciones e ideas: 1983-2008. Buenos Aires: Biblos, 2010. p. 137-160.

ROUSSO, Henry. "A memória não é mais o que era”. In: AMADO, Janaína; FERREIRA, Marieta de Moraes (Coords.). Usos \& abusos da história oral. Rio de Janeiro: Editora FGV, 2006.

SALVI, Valentina. "De vencedores a víctimas: 25 años de memoria castrense". In: Temas y debates. Buenos Aires: n.17, 93-115, agosto 2009.

SARLO, Beatriz. Tempo Passado: cultura da memória e guinada subjetiva. São Paulo: Companhia das Letras; Belo Horizonte: UFMG, 2007.

SORIANI, Hugo. “Ayer a la mañana”. Página/12, Buenos Aires, 17 set. 2011. Disponível em: http://www.pagina12.com.ar/diario/elpais/1-176956-2011-09-17.html Acesso em: 02 set. 2013.

VEZZETTI, Hugo. Pasado y Presente. Guerra, dictadura y sociedad en la Argentina. Siglo XXI, Buenos Aires, 2002

VEZZETTI, Hugo. Sobre la violencia revolucionara: memorias y olvidos. Buenos Aires: Siglo XXI Ed., 2009. 
Recebido em: 03/09/2013 Aprovado em: 06/11/2013

Universidade do Estado de Santa Catarina - UDESC Programa de Pós-Graduação em História - PPGH Revista Tempo e Argumento Volume 06 - Número 11 - Ano 2014 tempoeargumento@gmail.com 